\title{
What is Rose Rosette Disease?
}

\author{
H. Brent Pemberton ${ }^{1}$ \\ Texas A\&M AgriLife Research and Extension Center, Texas A\&M System, Overton, TX 75684
}

Kevin Ong

The Texas Plant Disease Diagnostic Laboratory, Texas A\&M AgriLife Extension, College Station, TX 77843

\author{
Mark Windham \\ Department of Entomology and Plant Pathology, The University of Tennessee, Knoxville, TN 37996 \\ Jennifer Olson \\ Department of Entomology and Plant Pathology, Oklahoma State University, Stillwater, OK 74078
}

\author{
David H. Byrne \\ Department of Horticultural Sciences, Texas A\&M University, College Station, TX 77843
}

Additional index words. Rosa, Rosa multiflora, virus, Emaravirus, eriophyid mite, mite transmission, witches broom, SCRI, USDA

\begin{abstract}
Rose rosette disease (RRD) is incited by a negative-sense RNA virus (genus Emaravirus), which is vectored by a wind-transported eriophyid mite (Phyllocoptes fructiphilus). Symptoms include witches broom/rosette-type growth, excessive prickles (thorns), discolored and distorted growth, and, unlike most other rose diseases, usually results in plant death. RRD is endemic to North America and was first described in Manitoba, Wyoming, and California in the 1940s. It has spread east with the aid of a naturalized rose species host and has become epidemic from the Great Plains to the East Coast of North America on garden roses in home and commercial landscapes where losses have been high. The disease was suggested to be incited by a virus from the beginning, but only recently has this been confirmed and the virus identified. The presence of the vector mite on roses has been associated with RRD since the first symptoms were described. However, more recently, the mite was demonstrated to be the vector of the disease and confirmed to transmit the virus itself. As a result of the RRD epidemic in North America and its effects on the national production and consumer markets for roses, a research team comprising five major universities (Texas, Florida, Tennessee, Oklahoma, and Delaware), a dozen growers and nurseries (all regions), six rose breeding programs (California, Wisconsin, Texas, and Pennsylvania), the major rose testing programs (Earth-Kind and AGRS), the major rose organization (American Rose Society), and the major trade organization AmericanHort has formed. This research project has been funded by the Specialty Crops Research Initiative through the U.S. Department of Agriculture (USDA) with the short-term objective of improving and disseminating best management practices (BMPs) and the long-term goal of identifying additional sources of resistance and developing the genetic tools to quickly transfer resistance into the elite commercial rose germplasm.
\end{abstract}

Rose rosette disease is incited by a negative-sense RNA virus (genus Emaravirus), which is vectored by a wind-dispersed eriophyid mite (P. fructiphilus) (Di Bello et al., 2015a; Laney et al., 2011). Symptoms on roses include witches broom/rosette type growth, excessive thorniness, and discolored and distorted growth. Unlike most other rose diseases, RRD usually results in plant death (Olson et al., 2015; Windham et al., 2014). Since being identified in the western United

Received for publication 2 Oct. 2017. Accepted for publication 28 Nov. 2017.

This paper is part of the workshop entitled, The Challenges of Rose Rosette Disease (RRD): An Update of the Combating RRD SCRI Project, presented on 9 Aug. 2016, during the ASHS Annual conference, Atlanta, GA.

This work was partially funded by the Robert E. Basye Endowment in Rose Genetics, the American Rose Society Research Endowment, and the USDA's National Institute of Food and Agriculture (NIFA) Specialty Crop Research Initiative project "Combating Rose Rosette Disease: Short Term and Long Term Approaches" (2014-51181-22644/ SCRI).

${ }^{1}$ Corresponding author. E-mail: b-pemberton@ tamu.edu.

This is an open access article distributed under the CC BY-NC-ND license (http://creativecommons. org/licenses/by-nc-nd/4.0/).
States and Canada, it has spread east with the aid of Rosa multiflora, a naturalized rose species host and has become widespread from the Great Plains to the East Coast of North America (Amrine, 2002). This epidemic has spread to garden roses in home and commercial landscapes where losses have been high. The popularity of landscape roses in gardens has increased greatly in recent years, resulting in widespread use of this type of rose in both home and commercial landscapes (Pemberton and Karlik, 2015). This and the occurrence of the disease in poorly managed landscapes where plants are not scouted and rogued have no doubt contributed to the spread of this deadly disease (Olson et al., 2015; Windham et al., 2014). The degree of plant loss threatens the use of garden roses by consumers and the rose production industry itself.

RRD is endemic to North America and was first described in Manitoba, Wyoming, and California in the 1940s. In 1940, Conners (1941) observed a "Witches' Broom (?virus)" symptom with a greatly increased number of spines affecting canes of an unnamed species of rose in Morden, Manitoba. Thomas and Scott (1953) reported receiving diseased specimens of Rosa rubrifolia grown as an ornamental from Lander, WY, in 1941. A specimen from near the same location, but on an unidentified native rose was received in 1942. Also in 1942, the same authors reported a specimen collection with similar symptoms from "a native rose, possibly Rosa pisocarpa, near Carrville in a mountainous area of Trinity County, CA." Symptoms included witches broom type growth, an indefinite chlorotic pattern in leaves, misshapen leaflets and flowers, and an increase in thorniness. They believed both of these collections to be representative of the same disease, which they referred to as rosette of rose. By the late 1960s, RRD symptoms were found in California on the native rose Rosa woodsii var. ultramontana (Wagnon and Nichols, 1966; Wagnon and Nichols, 1970).

Symptoms similar to those reported by Thomas and Scott (1953) were recognized at the University of Nebraska North Platte Experiment Station in 1957 by Viehmeyer (1961). By 1959, a 4- to 5-acre block of rose breeding stock at the station was heavily infected (Allington et al., 1968). In the same area, Viehmeyer (1961) indicated that the disease had been found in an area about 200 miles long and 50 miles wide. The same author also described the destruction of several miles of infected $R$. multiflora hedge in this particular area along with other centers of infestation. In addition to the symptoms described previously, Allington et al. (1968) 
noted the red leaf coloration in $R$. multiflora and a thickening of new, infected stems in most of the cultivars or species with which they worked.

In 1976, RRD was reported in Kansas (Crowe, 1983) and reports increased in the late 1970s in eastern Kansas and western Missouri. Symptoms were noted on rose hybrids in urban areas and on rose hybrids and $R$. multiflora hedges in rural areas. By 1982, symptoms were reported on cultivated hybrid roses in eastern Oklahoma (Crowe, 1983) and on both cultivated rose hybrids and $R$. multiflora hedges in northwestern Arkansas (Gergerich and Kim, 1983).

The first report of RRD east of the Mississippi River was found by Hindal et al. (1988) who described infestations in naturalized stands of R. multiflora in Illinois (1985), Kentucky
(1985), and Indiana (1986). In 1990, the first report came from Texas where it was found in production fields in east Texas where $R$. multiflora was used as a rootstock for garden rose production (Ong et al., 2015; Philley, 1995). By 1994, RRD distribution was as far east as Tennessee, Ohio, Pennsylvania, and West Virginia (Amrine, 2002) with reports mainly concerning infections in R. multiflora. In 1996, it was found in Maryland on $R$. multiflora (Tipping and Sindermann, 2000). In recent years, RRD has spread into garden rose plantings via the mite vector across the Midwest and Eastern United States, resulting in huge losses. In addition, it was found on a hybrid garden rose in a nursery in Florida in 2013 (Babu et al., 2014).

Abundantly apparent is the fact that the spread of RRD from western North America to the east has occurred through naturalized stands of $R$. multiflora. The history and status of the infestation of this introduced plant species along with the ecological damage it has caused have been well reviewed (Amrine, 2002; Amrine and Stasny, 1993). Rosa multiflora is native to eastern China, Japan, and Korea and was introduced into North America in the 1800s for use as a rootstock, and also for wildlife, erosion control, "living fences," and informal hedges (Amrine, 2002; Hindal et al., 1988; Hong et al., 2012). It soon spread from the original plantings and is now listed as a noxious weed in at least 10 states (Amrine and Stasny, 1993). The use of RRD as a biological control for $R$. multiflora has been proposed and studied (Amrine, 2002; Amrine and Stasny, 1993; Epstein and Hill, 1999). However, this work has been opposed

Table 1. Investigators and key collaborators working on the Specialty Crop Initiative Project Combating Rose Rosette: Short Term and Long Term Approaches.

\begin{tabular}{|c|c|c|c|}
\hline$\overline{\text { Name }}$ & Specialty & Responsibility & Location \\
\hline David H. Byrne, Project Director & Rose breeding and genetics & Rose breeding and genetics & $\begin{array}{l}\text { Department of Horticultural Sciences, Texas } \\
\text { A\&M University, College Station, TX }\end{array}$ \\
\hline Mark Windham & Plant pathology & Screening for resistance, BMP & $\begin{array}{l}\text { Entomology and Plant Pathology Department, } \\
\text { University of Tennessee, Knoxville, TN }\end{array}$ \\
\hline Brent Pemberton & Plant physiology, horticulturist & Outreach, rose evaluation trials & $\begin{array}{l}\text { Texas A\&M AgriLife Research and Extension } \\
\text { Center, Overton, TX }\end{array}$ \\
\hline Frank Hale & Entomologist & BMP & $\begin{array}{l}\text { Soil, Plant, and Pest Center, The University of } \\
\text { Tennessee, Nashville, TN }\end{array}$ \\
\hline Mathews Paret & Plant pathologist & Diagnostic techniques & $\begin{array}{l}\text { North Florida Research and Education Center, } \\
\text { Quincy, FL }\end{array}$ \\
\hline Francisco Ochoa Corona & Plant pathologist & Diagnostic techniques & $\begin{array}{l}\text { Department of Entomology and Plant } \\
\text { Pathology, Oklahoma State University, } \\
\text { Stillwater, OK }\end{array}$ \\
\hline John Hammond & Plant pathologist & Diagnostic techniques & $\begin{array}{l}\text { Floral and Nursery Plants Research Unit, } \\
\text { USDA/ARS, Beltsville, MD }\end{array}$ \\
\hline Tom Evans & Plant pathology, genetics & Screening for resistance & $\begin{array}{l}\text { Department of Plant and Soil Sciences, } \\
\text { University of Delaware, Newark, DE }\end{array}$ \\
\hline Jennifer Olson & Plant pathologist & $\begin{array}{l}\text { Outreach, diagnostics } \\
\text { validation, screening for } \\
\text { resistance }\end{array}$ & $\begin{array}{l}\text { Department of Entomology and Plant } \\
\text { Pathology, Oklahoma State University, } \\
\text { Stillwater, OK }\end{array}$ \\
\hline Kevin Ong & Plant pathologist & $\begin{array}{l}\text { Outreach, monitoring network, } \\
\text { diagnostics validation }\end{array}$ & $\begin{array}{l}\text { The Texas Plant Disease Diagnostic Laboratory, } \\
\text { Texas A\&M AgriLife Extension, College } \\
\text { Station, TX }\end{array}$ \\
\hline Gary Knox & Extension horticulturist & Outreach & $\begin{array}{l}\text { North Florida Research and Education Center, } \\
\text { Quincy, FL }\end{array}$ \\
\hline Alan Windham & Extension plant pathologist & Outreach, social media & $\begin{array}{l}\text { Soil, Plant, and Pest Center, The University of } \\
\text { Tennessee, Nashville, TN }\end{array}$ \\
\hline Marco Palma & Extension economist & Marketing and economics & $\begin{array}{l}\text { Department of Agricultural Economics, Texas } \\
\text { A\&M University, College Station, TX }\end{array}$ \\
\hline David Zlesak & Rose breeding & Population creation & $\begin{array}{l}\text { Department of Plant and Earth Sciences, } \\
\text { University of Wisconsin, River Falls, WI }\end{array}$ \\
\hline Don Holeman & Rose breeding & Population creation & Enfield, CT \\
\hline Marco Bink & Bioinformatics & Genetic analysis & $\begin{array}{l}\text { Plant Research Institute, Wageningen, The } \\
\text { Netherlands }\end{array}$ \\
\hline Eric van de Weg & Bioinformatics & Genetic analysis & $\begin{array}{l}\text { Plant Research Institute, Wageningen, The } \\
\text { Netherlands }\end{array}$ \\
\hline
\end{tabular}

$\mathrm{BMP}=$ best management practice; USDA/ARS $=$ U.S. Department of Agriculture/Agricultural Research Service. 
by the American Rose Society and by rosarians in general (Amrine, 2002).

The determination of the disease agent that causes RRD also has a long history. In 1953, Thomas and Scott suggested a virus as the cause of a witches broom symptom in rose and demonstrated graft transmission of the disease agent. Allington et al. (1968) referred to this disease agent as Rose rosette virus (RRV). Many years later, Gergerich and Kim (1983) reported double membranebound virus-like particles in cells of rose plant tissue infected with RRD. Doudrick et al. (1987) extracted the infectious agent and demonstrated transmission by drop inoculation or grafting. Di et al. (1990) found four unique virus-like double-stranded RNAs associated with RRD symptoms in $R$. multiflora. These were graft transmissible, but not through seed or fruit. Finally, Laney et al. (2011) with further work carried out by Di Bello et al. (2015b) characterized the causal disease agent as RRV, a negative-sense RNA virus and new member of the genus Emaravirus. The presence of the virus was perfectly correlated with RRD disease symptoms.

About the same time that Conners (1941) observed the witches broom symptom on rose in Manitoba, Keifer (1940) reported the presence of the eriophyid mite $P$. fructiphilus on Rosa californica in California. There is no indication in the literature that either author knew of the other's observations. Indeed, $R$. californica appears to be resistant to RRD when inoculated by grafting (Thomas and Scott, 1953). In 1966, Keifer found P. fructiphilus (as the junior synonym Phyllocoptes slinkardensis) on Rosa ultramontana (now known as $R$. woodsii var. ultramontana) (Amrine et al., 1995; Keifer, 1966). Keifer suggested this mite to be a vector of the disease associated with the witches broom symptom on the sample he examined that he reported to be collected by H.K. Wagnon on 30 May 1966 from Mono County, CA (Keifer, 1966). Keifer was most likely examining the same sample that Wagnon and Nichols used for reporting the presence of the witches broom (rosette of rose) pathogen (as mentioned above) because of the host, the location and date of collection, and the collector being the same in both reports (Keifer, 1966; Wagnon and Nichols, 1966). Allington et al. (1968) reported P. fructiphi$l u s$ as a vector for infection of $R$. multiflora with RRD. Twenty years later, Amrine et al. (1988) confirmed the mite as a vector for RRD infection. Root graft experiments indicated that the infection was due to a viruslike agent and not a reaction to mite feeding. Kassar and Amrine (1990) demonstrated that mites survive only on green living tissue and Zhao (2000) reported that mites develop only on tender rapidly growing shoots and are disseminated aerially. Recently, Di Bello et al. (2015a) reported the presence of RRV in rose mites and demonstrated mite transmission of the viral disease agent that causes RRD.

Thus, three players in this disease epidemic are described: the virus pathogen, the mite vector, and the reservoir of a host plant. Of interest is the fact that the RRD epidemic was not caused by the introduction of a causal disease agent or even a vector for the virus, both of which are endemic to North America. What assisted the spread of this disease from the west to the east of the continent was the reservoir of naturalized stands of a very susceptible host plant ( $R$. multiflora) that was introduced across a large geographical area for an entirely different purpose.

As a result of the RRD epidemic in North America and its effects on the national production and consumer markets for roses, a research proposal to study this disease was funded by the Specialty Crops Research Initiative through the USDA. The proposal was developed in collaboration with the rose industry beginning with the Rose Rosette Conference organized by Star Roses and Plants (West Grove, PA) and the Garden Rose Council in April of 2013. At this conference, which brought together trade associations, growers, breeders, landscape management firms, botanical gardens, federal regulatory agencies, biocontrol corporations, consultants, state plant disease diagnostic laboratories, and researchers from both the state and federal levels, a plan was developed to direct future research and serve as an outline for the resultant proposal. Over a period of months, a research and extension team that involved plant pathologists, rose breeders and geneticists, molecular geneticists, an entomologist, agricultural economists, marketing experts, and extension personnel was developed to tackle RRD. This team is from state, federal, and private organizations from Texas, Oklahoma, California, Florida, Tennessee, Delaware, Pennsylvania, Maryland, Wisconsin, and Connecticut (Table 1). The rose industry also committed their resources to the project.

Thus, this project and its objectives are industry driven and initiated. It is built on a research and industry community comprising five major universities (Texas, Florida, Tennessee, Oklahoma, and Delaware), a federal research agency (USDA-ARS), a dozen growers and nurseries (all regions), six rose breeding programs (California, Wisconsin, Texas, and Pennsylvania), the major rose testing programs (Earth-Kind and AGRS), the major rose organization (American Rose Society), and the major trade organization AmericanHort.

In the short term, this project will expand, refine, and develop existing BMPs through understanding the biology of the host-virusvector interaction and work with AmericanHort to expand the existing information pipeline via publications, presentations, and demonstrations to convey the use and value of these BMPs for managing RRD to stakeholder groups. The long-term goal is to identify additional sources of resistance and the genetic tools to quickly transfer resistance into the elite commercial rose germplasm.

$\mathrm{RRD}$ is a major concern for growers and consumers alike. Consumers and producers will benefit from RRD-resistant roses through the reduced use of chemicals (miticides) in the landscape leading to sustainable gardening and production systems. Breeding tools and approaches developed in this project will benefit breeders and producers by allowing quicker development of RRD-resistant roses as well as resistance to other fungal, bacterial, and viral diseases. According to our 2012-13 survey of more than 1500 consumers and industry participants, disease resistance is the most desired trait in new rose cultivars (Byrne, 2015; Waliczek et al., 2015). Roses are one of the most economically important ornamental plants in North America so that the findings from these studies will strengthen this industry and support the use of a sustainable and much loved plant by consumers across the continent.

\section{Literature Cited}

Allington, W.B., R. Staples, and G. Viehmeyer. 1968. Transmission of Rose rosette virus by the eriophyid mite Phyllocoptes fructiphilus. J. Econ. Entomol. 61(5):1137-1140.

Amrine, J.W., Jr. 2002. Multiflora rose, p. 265-292. In: R.V. Driesche, B. Blossey, M. Hoddle, S. Lyon, and R. Reardon (eds.). Biological control of invasive plants in the eastern United States. USDA For. Serv. Publ. FHTET-2002-04.

Amrine, J.W., Jr., D.F. Hindal, T.A. Stasny, R.L. Williams, and C.C. Coffman. 1988. Transmission of the rose rosette disease agent to Rosa multiflora by Phyllocoptes fructiphilus (Acari: Eriophyidae). Entomol. News 99(5):239-252.

Amrine, J.W., Jr. A. Kassar, and T.A. Stasny. 1995. Phyllocoptes fructiphilus (Acari: Eriophyidae), the vector of rose rosette disease, taxonomy, biology, and distribution. In: A.H. Epstein and J.H. Hill (eds.). Proc. Intl. Symp.: Rose Rosette and Other Eriophyid Mite-Transmitted Plant Disease Agents of Uncertain Etiology. Iowa State Univ., Ames, IA.

Amrine, J.W., Jr., and T.A. Stasny. 1993. Biocontrol of multiflora rose, p. 9-21. In: B.N McKnight (ed.). Biological pollution: The control and impact of invasive exotic species. Symp. Proc. Indiana Univ.-Purdue Univ. Indianapolis. Indiana Acad. Science, Indianapolis, IN.

Babu, B., H. Dankers, E. Newberry, C. Baker, T. Schubert, G. Knox, and M. Paret. 2014. First report of Rose rosette virus associated with rose rosette disease infecting Knockout roses in Florida. Plant Dis. 98(10):1449.

Byrne, D.H. 2015. Advances in rose breeding and genetics in North America. Acta Hort. 1064: 89-98.

Conners, L. 1941. Twentieth annual report of the Canadian plant report survey 1940. Dominion Can. Dept. Agr. Sci. Serv.

Crowe, F.J. 1983. Witches' broom of rose: A new outbreak in several central states. Plant Dis. 67:544-546.

Di, R., J.H. Hill, and A.H. Epstein. 1990. Doublestranded RNA associated with the rose rosette disease of multiflora rose. Plant Dis. 74:56-58.

Di Bello, P.L., T. Ho, and I.E. Tzanetakis. 2015a Identification of the rose rosette disease agent. Acta Hort. 1064:295-298.

Di Bello, P.L., T. Ho, and I.E. Tzanetakis. 2015b. The evolution of Emaraviruses is becoming more complex: Seven segments identified in the causal agent of rose rosette disease. Virus Res. 210:241-244.

Doudrick, R.L., M.F. Brown, J.A. White, and D.F. Millikan. 1987. Graft and mechanical transmission of the rose rosette agent. Trans. Missouri Acad. Sci. 21:81-86. 
Epstein, A.H. and J.H. Hill. 1999. Status of rose rosette disease as a biological control for multiflora rose. Plant Dis. 83(2):92-101.

Gergerich, R.C. and K.S. Kim. 1983. A description of the causal agent of rose rosette disease. Arkansas Farm Res. 32(3):7.

Hindal, D.F., J.W. Amrine, R.L. Williams, and T.A. Stasny. 1988. Rose rosette disease on multiflora rose (Rosa multiflora) in Indiana and Kentucky. Weed Technol. 2(4):442-444.

Hong, C., M.A. Hansen, and E. Day. 2012. Rose rosette disease. Virginia Coop. Ext. Publ. 450620 .

Kassar, A. and J.W. Amrine, Jr. 1990. Rearing and development of Phyllocoptes fructiphilus (Acari: Eriophyidae). Entomol. News 101(5): 276-282.

Keifer, H.H. 1940. Eriophyid studies VIII. Bul. Calif. Dept. Agr. 29(1):30-43.

Keifer, H.H. 1966. Eriophyid studies B-21. Bur. Entomol., California Dept. Agr.

Laney, A.G., K.E. Keller, R.R. Martin, and I.E. Tzanetakis. 2011. A discovery 70 years in the making: Characterization of the rose rosette virus. J. Gen. Virol. 92:1727-1732.

Olson, J., E. Rebek, and M. Schnelle. 2015. Rose rosette disease. Oklahoma Coop. Ext. Serv. Bul. EPP-7329.

Ong, K., M. Giesbrecht, D. Woodson, and L. Miller. 2015. Rose rosette disease demystified. Texas A\&M AgriLife Ext. Bul. EPLP-010.

Pemberton, H.B. and J.F. Karlik. 2015. A recent history of changing trends in USA garden rose plant sales, types, and production methods. Acta Hort. 1064:223-234.

Philley, G.L. 1995. Concerns of extension, p. 77-78. In: A.H. Epstein and J.H. Hill (eds.). Proc. Intl. Symp.: Rose Rosette and Other Eriophyid MiteTransmitted Plant Disease Agents of Uncertain Etiology. Iowa State Univ., Ames, IA.

Thomas, H.E. and C.E. Scott. 1953. Rosette of rose. Phytopathology 43:218-219.

Tipping, P.W. and A.B. Sindermann. 2000. Natural and augmented spread of rose rosette disease of multiflora rose in Maryland. Plant Dis. 84(12): 1344 .
Viehmeyer, G. 1961. A “new” disease of roses. Amer. Rose Annu. 46:98-101.

Wagnon, H.K. and C.W. Nichols. 1966. Report of new or unusual plant pathogen: Witches' broom (Rosette of Rose). P1 Path A-66-11. Bur. Plant Pathol., California Dept. Agr., Sacramento, CA. 1 Sept.

Wagnon, H.K. and C.W. Nichols. 1970. Report of new or unusual plant pathogen: Witches' broom (Rosette of Rose). P1 Path A-70-7. Bur. Plant Pathol., California Dept. Agr., Sacramento, CA. 1 Dec.

Waliczek, T.M., D.H. Byrne, and D.J. Holeman. 2015. Growers' and consumers' knowledge, attitudes and opinions regarding roses available for purchase. Acta Hort. 1064:235-240.

Windham, M., A. Windham, F. Hale, and J. Amrine, Jr. 2014. Observations on rose rosette disease. Amer. Rose 42(9):56-62.

Zhao, S. 2000. Study of dispersal and diversity of eriophyid mites (Acari: Eriophyoidea). West Virginia Univ., Morgantown, WV, PhD Diss. 